(A similar version of this piece can be found in Catherine Strong and Michelle Phillipov eds. Stuck in the Middle: The Mainstream and Its Discontents; Selected Proceedings of the 2008 IASPM-ANZ Conference, 2009, pp. 68-75.)

\title{
"A West Indian? You must be joking! I come out of the East End." Kenny Lynch and English racism in the 1950s and 1960s
}

In the 1990s and 2000s Kenny Lynch remains Britain's most long-standing black entertainer. The statement I use in the title of this article, spoken in a broad cockney accent, comes from the 1965 film, Dr Terror's House of Horrors, in which Lynch plays Sammy Coin-pronounced like the Jewish 'Cohen', referencing another group problematically positioned in British society-a calypso and jazz singer who has a contract to work in a club in Haiti. Like his character, Lynch is a cockney. He was born in Stepney in 1939 just a few months before the start of the Second World War. He is, then, as his character suggests, not a part of the West Indian migration to Britain that is now conventionally considered to have begun with the docking of the Empire Windrush at Tilbury in June 1948.

In this article I want to think about some of the ways that British racism influenced Lynch's reception. Given the constraints of length I shall confine myself to a limited selection of examples. In Who Do We Think We Are?, Yasmin Alibhai-Brown quotes Charles Moore, then editor of the Daily Telegraph, in 1991: "Britain is basically English speaking, Christian and white and if one starts to think that it might become basically Urdu speaking and Muslim and brown one gets frightened"(Charles Moore quoted in Alibhai-Brown, 2000:10). Race has been central to the British construction of identity. Small numbers of people, how many has varied over time, identified as notwhite have been tolerated provided that these people have remained invisible and marginal to Britain's social and cultural life. Peter Fryer has outlined the results of a study conducted in 1955 into British perceptions of black people: 
More than two-thirds of Britain's white population, in fact, held a low opinion of black people or disapproved of them. They saw them as heathens who practised head-hunting, cannibalism, infanticide, polygamy, and 'black magic.' They saw them as uncivilized, backward people, inherently inferior to Europeans, living in primitive mud huts 'in the bush,' wearing few clothes, eating strange foods, and suffering from unpleasant diseases....They believed black men had stronger sexual urges than white men, were less inhibited, and could give greater satisfaction to their partners.(Fryer, 1984:374)

This understanding of black people is the backdrop for the attempt to make Lynch a pop star. Lynch, and his generation of British blacks which also includes the singers Shirley Bassey and Cleo Laine, grew up in a social environment of toleration. The migrants that arrived after 1948, and their children, found themselves in an evolving context of racial anxiety. Lynch himself signals the distinction like this: 'Being a cockney, I never had any trouble in those days [when he was growing up], because there weren't many black people around, and the few that were around...were more a novelty than anything else' (Pines, 1992:109). Having a cockney accent, Lynch suggests, gave him a key, but not crucial, marker of Englishness.

Lynch was one of eleven children (Lynch quoted in Pines, 1992:108). His father was from Barbados, a seaman who settled in London when he was sixteen. Lynch's mixed-race mother came from Canning Town (Wilmer, 2003). Maxine Daniels, the wellknown jazz singer born Gladys Lynch, was Lynch’s sister. Daniels, her married name, was eight years older than Lynch. There is a story that Lynch's first public appearance on stage was singing with his sister in 1950 when he was eleven (Reg on 45RPM website).

Lynch was called up for National Service in 1956. By this time he was already singing with dance bands. He passed his time in the army as a boxer and went back to singing after he was demobbed in 1958, joining Bob Miller’s Miller Men, a dance band which performed at London's Mecca dance halls. Commenting on white, British racial 
prejudice in the 1960s in a book published in 1971, Dilip Hiro, in Black British/White British, writes that:

The image of a coloured man as a publican or a businessman clashes with the post-slavery image of him as, at best, an agriculturalist, a crooner, a boxer, or a sportsman complemented by the contemporary image of a busconductor, mill-worker or a foundry-man.(Hiro, 1973:281)

Hiro’s 'contemporary image' refers to the sort of low-level service and industrial jobs into which the post-Empire Windrush migrants of the 1950s and 1960s were channelled. Lynch, who writes that he "didn't really think about racial prejudice until [he] was about sixteen,”(Pines, 1992:109) nevertheless took up two of the earlier occupations conventionally open to black people.

Lynch continued to sing jazz standards in Soho clubs until a fateful meeting with Shirley Bassey. Bassey's father was a Nigerian sailor, her mother was a white Yorkshire woman. The couple lived in the docks area of Cardiff known as Tiger Bay. Born in 1937, Bassey was two years older than Lynch. Lynch has told the story of Bassey’s intervention many times. In 1960:

Shirley Bassey came in a club I was singing in called Romano’s. I was doing standards, 'All The Things You Are,' 'Lover Man.' She said I think you ought to make records.(Lynch quoted in Tyler, 2004)

Lynch, like Bassey, had a repertoire that ranged across dance band and jazz standards. By the post-war era there was a general idea that jazz had been acceptably whitened as it had been transformed into dance music. This development had been in train since the 1920s in the United States with the Art Hickman Orchestra and, later, the orchestras of band leaders like Paul Whiteman, Benny Goodman and Glenn Miller. Nevertheless, there was still a memory of its black origin. George McKay has noted that "jazz has predominantly been understood by its white British fans to be a black American form” (McKay, 2005:90). It was acceptable for black British singers to perform this whitened form of jazz, bringing to this now safely whitened music an exotic edge of Otherness. In Britain, the new form of bebop had a very limited audience. Harry Shapiro writes that: 
'The audience for bebop was tightly located in London's West End, the territory of 'wide boys', cool and aloof, seekers after the secret and deliberately difficult black jazz of Bird, covetous of hipster chic and the culture of the zoot suit' (Shapiro, 1996:42). In later years the descendents of these enthusiasts for African-American music would be identified as mods. We should note here, however, that black British artists did not perform with trad jazz bands. McKay remarks that: "The whiteness of the traditional jazz boom in Britain in the late 1950s has been touched on by cultural critics" and goes on to suggest that, "of all the exported forms of jazz, trad is ... the nearest to blackface, to minstrelsy"(McKay, 2005:123). Albeit that trad referred back to the early jazz of New Orleans, it was a British musical form (see Moore, 2007). Trad was the most popular jazz form among the general population giving Acker Bilk, for example, eleven top fifty hits between 1960 and 1963.

Bassey's manager, Jean Lincoln, set up an audition for Lynch with EMI's head of A\&R, Wally Ridley. Ridley, for unexplained reasons, decided that Lynch should be promoted as a pop singer rather than a jazz singer. Lynch's career in the early 1960s was the first attempt to produce a black British pop star for a white, British teenage audience. Between 1960 and 1969, Lynch released twenty-four singles. None made the top forty after 1965's 'I'll Stay By You' which got to number twenty-nine. Two singles got to number ten, 'Up On The Roof' in 1962 and 'You Can Never Stop Me Loving You' the following year. Lynch appeared frequently on pop music television shows, Thank Your Lucky Stars (which started on ITV in 1961) and Rediffusion's more cutting edge Ready, Steady, Go! (which started in 1963).

In the mid-1960s Lynch also became a well-regarded song-writer. On the Small Faces first album, Lynch wrote 'Sorry She’s Mine' and co-wrote 'Sha-La-La-La Lee' with Mort Shuman, the American composer who had worked with Doc Pomus, and 'You Better Believe It' with Jerry Ragovoy, the American who composed numerous rhythm and blues and soul hits in the 1960s such as Lorraine Ellison's 'Stay With Me.' He also co-wrote with Shuman Cilla Black's 'Love's Just A Broken Heart' which reached number five in 1966 and her single 'What Good Am I' which got to number twenty-four in 1967. Lynch's songs were also sung by Dusty Springfield, Billy J Kramer and the Dakotas and the Swinging Blue Jeans. He even had a song of his, 'Follow Me,' released 
in 1965 as a single by the Drifters in the United States - though it did not chart. Lynch was a successful song-writer through the mid-1960s beat boom era in Britain when he, himself, was unable to get a hit. While in part this can be attributed to the shift away from solo singers to groups we also need to remember how very white those groups were.

There were no black beat boom groups and the only two of the British rhythm and blues groups, such as the Rolling Stones, the Yardbirds and the Animals, had a black membership_-Geno Washington and the Ram Jam Band (Washington was a demobbed black American serviceman, the Ram Jam Band were a local white group) and Jimmy James and the Vagabonds who had migrated from Jamaica. Through the mid-1960s, blackness became a mark of acceptable Otherness in British popular music only if those black singers were African-American. African-American music sung by African Americans was starting to become popular with mods, an upwardly mobile, workingclass subculture. Anthony Marks writes that,

the mods were largely responsible for the wider acceptance of soul music.

The popularity of the music among such a loud and vociferous minority resulted in the music's breaking through into the mainstream.(Marks in Oliver ed. 1990:104)

The mods had picked up on soul music because it could be associated with their rejection of normative British musical taste. When the music started to achieve broader popularity, African Americans remained identified as a racially Othered group. As black, they could be accepted because they were American not British. While Geno Washington, understood to be a black British resident, managed two top ten albums in 1966 and 1967 no single reached higher than number 39 on the chart, suggesting his limited cult following among those who values African-American soul and rhythm and blues, mods and their fellow travellers. Jimmy James and the Vagabonds, who had a similar specialised audience, finally reached the singles chart in 1968 when their cover of Neil Diamond's countryish 'Red Red Wine' got to number 36. In this racialised context, a black British singer like Lynch had to appear as white as possible in order to be accepted. The lack of black beat groups suggest that black artists could not be accepted playing the music which, while having African-American origins, was being indigenised through an 
amalgamation with music hall and other forms of traditionally English music — there had been only a very minimal involvement of blacks in that other indigenised music form of the 1950s, skiffle. This structure continued through the 1990s when there were no black groups involved in the BritPop movement.

\section{What Did Kenny Lynch Sing?}

When Ridley made the decision to market Lynch as a pop singer rather than a jazz singer he faced a major problem: how to make a black, London-born singer acceptable to a mass white, teenage market. Now, as I have argued elsewhere, many of the singers that gained popularity in Britain during the 1960s had an edge of exoticism (Stratton, 2009/10). They were considered Other enough to be identified as different and in some sense special and intriguing but familiar enough for British audiences to feel comfortable with them. Singers in this category reach back at least as far as Al Bowlly and, in the 1950s and 1960s, include Cliff Richard, who was Anglo-Indian, Alma Cogan and Helen Shapiro, who were Jewish, and Dusty Springfield, whose parents were Irish. The key to these artists' success was the balance between the two aspects of their identity. The Otherness had to be permeated by a perception of their familiarity as ordinary English young people. The problem with Lynch was that his visible blackness was a very obvious marker of difference, one which marked Lynch as not-English in a totalising way. One way in which Lynch countered this was through his obvious cockney accent. Another was through the songs that he sang.

In the late 1950s there was an attempt to break Lynch's jazz-singing sister, Maxine Daniels, into a mass, pop audience. It was not successful-none of the six singles she released made the charts. The first, titled 'Coffee Bar Calypso', was released in 1957. Its use of calypso sought to capitalise on the Jamaican-American, Harry Belafonte's popularisation of calypso. However, in Britain, calypso was associated more with the post-Empire Windrush Trinidadian migrants and, therefore, was likely to be more a source of anxiety than to have connotations of exotic tropical islands. In allying Daniels with this group it emphasised her Otherness and it is, therefore, no surprise that the song did not chart. Daniels' second single was 'Why Should I Care?'. This was written by Jimmie Davis, who is also credited with writing 'You Are My Sunshine'. 
Davis was an early country singer and it is not a coincidence that Daniels' fifth single, released in 1958, was a classic early country song, 'When It's Springtime In The Rockies', a country standard but most well-known through Gene Autry’s 1938 version.

Lynch's early singles likewise had a country influence to them. His first single, released in 1960, was a cover of Harold Dorman's pop-country hit of the same year, 'Mountain Of Love'. Dorman's version reached number twenty-one on the American Billboard chart. Lynch achieved a respectable, number thirty-three on the UK chart. His second single was a cover of Pee Wee King's country-styled 'Slow Poke' which had got to number three on the Billboard chart in 1951. Lynch's version was retitled 'Slow Coach' to make it more familiar for a British audience.

The point I want to make here is that country and western songs were central to the attempt to popularise both Daniels and Lynch. In Britain, the dominant understanding of country music was that it was a white musical form. Michael Pickering explains that:

Historically, country music was closely related to both African-American popular music and blackface acts. In its own self-conception it is usually constructed as all-white and non-commercial in origin, with a strong image of downhome authenticity and rugged individualism.(Pickering, 2008:216)

When rock and roll had arrived in Britain, the lack of knowledge of African-American music had meant that the white, country aspect, often up-dated in the form of rockabilly, was the generally understood source for the new music. In this context we should remember that Billy Fury, who Bruce Eder describes as "the real article from day one"(Eder) in contrast to the likes of Tommy Steele, Cliff Richard and Marty Wilde, recorded much of his first album in the rockabilly style. Fury himself acknowledged the importance of country music to his style, saying that: "Hank Williams and some of the country and western singers were singing about real life and how it feels when you get let down, so I kind of tagged on to their stuff”(billyfury.com) Steele, Britain's pioneer rock'n'roller pop star, also valued Williams as an influence and recorded two of his songs, 'Honky-Tonk Blues' and 'Kaw-Liga' on his live first album, Tommy Steele Stage 
Show. Steele also covered Guy Mitchell's country-pop versions of country singer Marty Robbins' 'Singin' The Blues' and 'Knee Deep In The Blues' as his third and fourth singles, reaching number one and number 15 respectively. Thus, giving British black artists country songs to sing was a way of whitening them, and therefore hopefully making them more acceptable, to a British audience.

This is a background for an unsuccessful release of Lynch's which, nevertheless, is the one for which he remains most well-known. In 1963, Lynch was on a package tour headlined by Helen Shapiro which included the Beatles whose second single, 'Please, Please Me,' was beginning to climb the charts. At this time there were plans for Shapiro to record an album in Nashville. The story goes that John Lennon and Paul McCartney were asked if they had anything suitable for her. The pair rapidly composed 'Misery.' However, Norrie Paramour, at EMI, decided that the song was not the kind of material he was looking for Shapiro. Lynch quickly asked if he could record the song, becoming the first artist to cover a Lennon and McCartney composition. We can imagine that one of the reasons for Lynch's eagerness to record the song was its country style. The Beatles went on to release their own version on their first album, Please, Please Me. While both versions have a similar tempo, Lynch's vocal is much smoother than Lennon and McCartney's harmony. Similarly, the Beatles' backing for the song has a rockier feel. One reason for this is that Bert Weedon was asked to provide the lead guitar work for Lynch's version. Weedon is credited with being a major influence on the introduction to Britain of the guitar as a popular instrument. He was technically highly proficient but he lacked the feel of a rock and roll guitarist. Consequently, ironically, Lynch's version of 'Misery' sounds much whiter than the Beatles' version. Indeed, when he heard Lynch's version an annoyed Lennon is said to have asked Lynch why he hadn't asked him to play lead on the recording. Richie Unterberger describes Lynch's version as, "featuring strings and the sort of weedy surf-country reverb guitar typical of early-'60s, pre-Beatles British pop-rock”(Unterberger).

There is a further aspect to Lynch's recording of 'Misery.' Lynch had been going to release his version of 'You Can Never Stop Me Loving You.' This song was written by the English composer, Ian Samwell and Jean Slater. Samwell had written Cliff Richard's first hit, 'Move It.' Lynch shelved 'You Can Never Stop Me Loving You' and 
it was covered in the US by the country-pop singer, Johnny Tillotson. Tillotson had charted consistently in the American top fifty since 1960. His version got to number eighteen. Lynch released his own version in Britain in 1963 after 'Misery' and reached number ten with it showing that there was still a market for that kind of countrified rock and roll in Britain.

Lynch’s 'Misery' needed to sound whiter because of Lynch's blackness in order to gain acceptance from the white, British audience. However, by 1963, that audience was listening to blacker music, provided that it was sung by British white, or not-quitewhite, singers. Alternatively, African-American music sung by African Americans was starting to become popular, a development pioneered, as we have seen, by the mods. Lynch, and other British, black singers could not be accepted singing the same music because they were British. Being British, they did not have same exotic quality as black Americans. There were, as I have remarked before, no black British beat groups.

The Brill Building sound is the term used to describe the music associated with the writers and producers who worked out of New York's Brill Building and buildings close by in the late 1950s and early 1960s. The majority of these people, such as Lieber and Stoller, Bacharach and David, Pomus and Shuman, the latter of whom would subsequently write with Lynch, were Jewish. Many of the singers who sang their songs, such as the Drifters, Howard Tate, Ben E King, and the girl groups such as the Shirelles and the Ronettes, the latter of whom was produced by Phil Spector, were black. The music was successfully aimed at a white, teenage audience.

Lynch first came into contact with the Brill Building composers through meeting Mort Shuman in London (Oldham, 2001:160). Lynch got a song writing deal with Aberbach who paid for him to go to New York. He returned having made numerous contacts and with Goffin and King's composition, 'Up On The Roof'(Tyler, 2004). Lynch also released Bacharach and David's 'The Story Behind My Tears,' which was written specially for him, in 1961 (Dominic, 2003:58-59) and, immediately prior to 'Up On The Roof' the Bill Giant, Bernie Baum and Florence Kaye composition, 'Puff (Up In Smoke).' Lynch, as a black British singer trying to reach a white audience, was using the same song writers, and sometimes the same songs, as were successful in the United States 
with white audiences when sung by African Americans. Lynch struggled to achieve that same success in Britain. In the United States, the Drifters' 'Up On The Roof' reached number four on the Rhythm and Blues chart, selling to African Americans, and number five on the pop chart selling to white teenagers.

In Britain, 'Up On The Roof' was Lynch's greatest success along with the country-pop 'You Can Never Stop Me Loving You.' 'The Story Behind My Tears' did not chart, though this may have in part been because it was simultaneously covered by Gary Miller who had had a hit previously with Bacharach and David's 'The Story Of My Life'. 'Puff' had got to number thirty-three and, in 1964, Lynch's version of 'Stand By Me,' the highly emotive ballad based on a gospel song and written by Ben E King with Leiber and Stoller, which had reached number four for King on the American pop chart and topped the Rhythm and Blues chart in 1961, only made number forty-nine on the UK chart. King had been the lead singer with the Drifters. In 1961, King's version had got to number twenty-seven on the UK chart. Lynch's version was much smoother and more controlled than King's. Lynch's version may well have been unsuccessful because, coming after the British cultural shift in the acceptance of African-American vocal stylings associated with the Beatles and the rhythm and blues groups like the Rolling Stones, Lynch's version was received as simply too bland by white, British teenagers.

As a black singer trying to reach a mass audience in Britain, Lynch was caught in a delicate balancing act. He had to sing material that would appear reassuringly white to a British audience that was anxious about the visible difference of a black, British singer. At the same time, as that same audience gradually accepted African-American vocal stylings, Lynch had to ensure that his performance, and his material, did not come over as too white, too bland, for his audience. Lynch managed to keep his balance, albeit never succeeding in having a record get higher than number ten in the chart, until his final chart entry, 'I'll Stay By You,' which got to number twenty-nine in 1965. Self-penned, 'Ill Stay By You' was the kind of big ballad with large orchestration that had been a perennial favourite with conservative British record buyers since the late 1950s. 'I'll Stay By You' signals Lynch's move away from trying to reach a pop audience and towards a less age-specific, more entertainment-oriented audience. It's also the same year that Lynch acted in Dr Terror's House of Horrors affirming his Englishness as 
compared with the West Indian migrants who started arriving in 1948. Nevertheless, to the white British he remained a black man.

Bibliography

Alibhai-Brown, Y (2000) Who Do We Think We Are?, London: Allen Lane

billyfury.com on the web at: http://www.billyfury.com/furyman.htm

Dominic, S (2003) Bacharach Song By Song, New York: Schirmer Trade Books

Eder, B 'Billy Fury' on the AllMusic Guide website at:

http://www.allmusic.com/cg/amg.dll?p=amg\&sql=11:hifwxqe5ldke T1

Fryer, P (1984) Staying Power: The History of Black People in Britain, London: Pluto Press

Hiro, D (1973) Black British, White British, New York: Monthly Press

Marks, A (1990) 'Young, Gifted and Black: Afro-American and Afro-Caribbean Music in Britain 1963-1968’ in Paul Oliver ed. Black Music In Britain: Essays on the AfroAsian Contribution To Popular Music, Milton Keynes: Open University Press

McKay, G (2005) Circular Breathing: The Cultural Politics of Jazz in Britain, Durham, NC: Duke University Press

Moore, H (2007) Inside British jazz: crossing borders of race, nation and class, Aldershot: Ashgate

Oldham, A (2001) Stoned: A Memoir of London in the 1960s, New York: St. Martin's Press

Pickering, M (2008) Blackface Minstrelsy in Britain, Aldershot: Ashgate

Pines, J (1992) Black and White in Colour: Black People in British Television Since 1936, London: British Film Institute

Stratton, J (2009/10) Chapter Seven ‘Not Quite English: Helen Shapiro’s Jewishness and English Exclusivity’ in Jews, Race and Popular Music, Aldershot: Ashgate

Tyler, K (2004) Liner notes for Nothing But the Real Thing, CD released on RPM

Unterberger, R Review of The Very Best of ... Kenny Lynch on the web at: http://www.allmusic.com/cg/amg.dll?p=amg\&sql=10:ajfyxqyjldke 
Wilmer, V (2003) 'Obituary of Maxine Daniels,' The Guardian, 30 ${ }^{\text {th }}$ October, on the web at: http://www.guardian.co.uk/news/2003/oct/30/guardianobituaries.artsobituaries

45rpm website for Kenny Lynch at: http://www.45-rpm.org.uk/dirk/kennyl.htm 